\title{
The Battle of Kars During the Russo-Turkish War (1877- 1878) in V. P. Meshcherskiy's 'Caucasian Travel Diary'
}

\section{V.P. Meshcherskiy'nin “Kafkas Seyahat Günlüğü”nde Rus-Türk Savaşı (1877-1878) sırasında Kars Muharebesi}

\section{Asl1 Yiğit Gülseven* (i)}

"Asst. Prof., Atılım University, Business School, Department of Political Science and Public Administration, Ankara, Turkey

\section{ORCID: A.Y.G. 0000-0002-9325-2965}

Corresponding author/Sorumlu yazar: Aslı Yiğit Gülseven,

Atılım University, Business School, Department of Political Science and Public Administration, Ankara, Turkey

E-mail/E-posta: asli.gulseven@atilim.edu.tr

\section{Submitted/Başvuru: 29.06.2020} Revision Requested/Revizyon Talebi: 20.10.2020

Last Revision Received/Son Revizyon:

02.11.2020

Accepted/Kabul: 13.12 .2020

\section{Citation/Atıf:}

Yigit Gulseven, Asli. "The Battle of Kars During the Russo-Turkish War (1877-1878) in V. P. Meshcherskiy's 'Caucasian Travel Diary."' Tarih Dergisi - Turkish Journal of History, 73 (2021): 195-213.

https://doi.org/10.26650/iutd.759817

\begin{abstract}
Travel notes and memoirs contain many contents that fill the gaps in official history, and are thus precious material for historians as primary sources. This study aims to explore the historical context of the Battle of Kars during the Russo-Turkish War of 1877-1878 by focusing on Vladimir Petrovich Meshcherskiy's travel notes and memoirs on the trip from Moscow to Kars during the war in 1877. Although there is a vast literature on the course and consequences of the Russo-Turkish War of 1877-1878, we have little first-hand information from the field to fill the gaps in our knowledge of the developments during and aftermath of the Kars attack. Meshcherskiy's travel diary does not only provide us with a close-up view of the Eastern front of the Russo-Turkish War, but it also sheds light on the attitude of the local people under the Russian siege. Although this diary provides a rich source of information from the viewpoint of Meshcherskiy, a prominent Russian journalist and novelist, it has never been used in the academic literature on the Russo-Turkish War of 1877-1878.
\end{abstract}

Keywords: Meshcherskiy, The Russo-Turkish War, The Caucasian Front, Kars, Russia

\section{Öz}

Seyahat notları, hatıratlar ve günlükler resmi tarih yazımındaki boşlukları dolduracak nitelikte birçok içeriğe sahiptir ve bundan dolayı tarihçiler için kıymetli kaynaklardır. Bu çalışmanın amacı, 93 Harbi'nde Kars Muharebesi'ndeki tarihsel bağlamı Vladimir Petrovich Meşçerski'nin 1877'de savaş sırasında Moskova'dan Kars'a yaptığı yolculuğunu konu alan "Kafkasya Seyahat Günlüğü"nden yola çıkarak irdelemektir. 93 Harbi'ne dair geniş bir literatür bulunmasına rağmen, Kars taarruzu esnasındaki ve sonrasındaki gelişmelere ilişkin bilgimizdeki eksiklikleri tamamlayacak cepheye dair ilk elden bilgiye pek sahip değiliz. Meşçerski'nin seyahat günlüğü 93 Harbi'nde doğu cephesine yakından bir bakış sağlamanın ötesinde Rus işgali altındaki yerel halkın tavırlarına ışık da tutmaktadır. Bu günlük gazeteci ve yazar Meşçerski'nin bakış açısından aktarılan önemli bir bilgi kaynağı sunmasına rağmen daha önce 93 Harbini konu alan akademik literatürde kullanılmamıştır.

Anahtar sözcükler: Meşçerski, 93 Harbi, Kars, Kafkas Cephesi, Rusya 


\section{Introduction}

Russia's failure in the Crimean War opened a new era for Tsarist foreign policy in the second half of the nineteenth century, diminishing Russia's prestige among the Western powers. ${ }^{1}$ In order to restore its prestige, Russia started to follow a revisionist foreign policy after the Paris Peace Agreement of $1856 .{ }^{2}$ Although the imperial administration focused on financial and military reforms to catch up with European modernization, and to avoid another war until these reforms would be completed, in 1877 Russia found itself in a new war with the Ottoman Empire. ${ }^{3}$ After invading Ardahan and Beyazıt, Russian forces attacked Kars in the summer and early autumn. However, they could not take the city under control until December 1877. The Ottoman Empire signed an armistice and the war ended in March 1878, by the Treaty of San Stefano (Yeşilköy). However, no one was pleased with the results of Treaty of San Stefano except Russia and thus the European powers, Russia and the Ottoman Empire met again at the Congress of Berlin on 13 July 1878. This treaty was an important breakpoint for both the Ottoman Empire and the Russian Empire. While the Ottoman Empire lost significant territories in the Balkans and South Eastern Anatolia, Russians succeeded both in diplomatic terms and in terms of territorial gains. Article 58 of the Berlin Treaty states that the Ottoman administration left the Elviye-i Selase (Kars, Ardahan, Batum) to the control of Russia. ${ }^{4}$

The aim of this study is to explore the details about the conquest of Kars by the Russian forces by focusing on the travel diary of a Russian journalist and novelist, Prince Vladimir Petrovich Meshcherskiy. ${ }^{5}$ In his travel diary 'Kavkazkiy Putevoy Dnevnik'6 (Caucasian Travel Diary), Meshcherskiy provides a vivid picture of the pre and post war days and the process of planning the attack on Kars. Moreover, he depicts the situation in the city and the life of the local people under the Russian siege.

1 For Russian foreign policy in the nineteenth century see Dominic Lieven, Empire: The Russian Empire and Its Rivals, Yale University Press, New Haven 2000.

2 See Leonid E. Gorizontov, 'The Crimean War as a Test of Russia's Imperial Durability,' Russian Studies in History, 51 (2012/1), pp. 65-94; Hakan Kırıml1, 'Emigrations from the Crimea to the Ottoman Empire during the Crimean War,' Middle Eastern Studies, 44 (2008/5), pp.751-773; Hakan Yavuz and Peter Sluglett, eds., War and Diplomacy. The Russo-Turkish War of 1877-78 and the Treaty of Berlin, Utah University Press, Salt Lake City 2011; M. S. Anderson, The Eastern Question, 1774-1923: A Study in International Relations, St Martin's, New York 1966.

3 For more details on the 1877-1878 War from a Soviet point of view see I. I. Rostunov, Russko-turetskaia voina 1877-1878, Voenizdat, Moscow 1977.

4 Mustafa Tanriverdi, 'The Treaty of Berlin and the Tragedy of the Settlers from the Three Cities' in Yavuz and Sluglett, ibid, pp. 449-452.

5 The translations from Russian to English are done by the author.

6 V. P. Meshcherskiy, Kavkazkiy Putevoy Dnevnik, 1878, Tipografiia G. E. Blagosvetlova, St. Petersburg 1878. 
The literature on the Russo-Turkish War of $1877-1878,{ }^{7}$ or the Eastern War, does not include insider information from the Caucasian front, especially about the local atmosphere during the war. In this regard, Meshcherskiy's travel diary is an invaluable source, which supplements the official accounts of the war. In his diary, Meshcherskiy provides significant details about the storming of Kars, as well as the physical and humanitarian conditions of the environment at the Eastern front. He also describes and compares the physical conditions of the Russian and Turkish armies in terms of efficiency, equipment as well as medical capabilities. His travel diary includes conversations and interviews with the Russian soldiers and commanders, providing details about their moods and motivations. Furthermore, it includes observations on the general characteristics of Turkish military officials as well as the Turkish and Armenian people inhabiting the region.

\subsection{A General View of the Structure and Content of the Diary}

The travel diary consists of 372 pages, and includes 41 headings starting from 15 October $^{8}$ until 23 November. ${ }^{9}$ The point of departure is the Ryazan train station, then it continues with a series of stages: Voronezh-Rostov (16-17 October), ${ }^{10}$ Vladikavkaz (18-21 October), ${ }^{11}$ Station of Mleta (22 October), ${ }^{12}$ Tiflis (23 October-5 November), ${ }^{13}$ Delican (7 November) ${ }^{14}$ Aleksandropol (Gümrü) (8-17 November), ${ }^{15}$ Vizinkev (17-18 November), ${ }^{16}$ Ardost (18-19 November) ${ }^{17}$ Veran-Kale (20-21 November), ${ }^{18}$ and Kars (22-23 November) ${ }^{19}$

7 See F. V. Greene, Report on the Russian Army and its Campaigns in Turkey in 1877-1878, Appleton, New York 1879; Quintin Barry, War in the East: A Military History of the Russo-Turkish War 1877-78, Helion, Solihull 2012; A. A. Zagiev, 'Osada Shturm Kreposti Kars Oseniu 1877 goda,' Vserossiyskie Millerovskie Chteniia, 6 (2018), pp. 210-214; James Reid, Crisis of the Ottoman Empire, Prelude to Collapse 1839-1878, Franz Steiner Verlag, Stuttgart 2000; B. M. Kolyubakin, Russko-Turetskaia Voyna, 1877-1878 gg. na Kavkaz i v Maloy Azii, Tipo-Tsintographiia A. G. Rozena, St. Petersburg 1906; V. A. Zolotarev, Rossiia i Turtsiia 1877-1878 gg., Nauka, St. Petersurg 1983; Bitva za Kavkaz v issledovaniiakh, dokumentakh i fotomaterialakh, ed. S. I Lintsa, PGLU, Pyatigorsk 2015; William Edward David Allen and Paul Muratoff, Caucasian Battlefields, A History of Wars on the Turco-Caucasian Border, 1828-1921, Cambridge University Press, New York 1953; Yavuz and Sluglett, ibid; Ian Drury and Raffaele Ruggeri, The Russo-Turkish War 1877, Osprey, London 1994.

' 3 October' is in Julian calendar, which the Russian Empire had adopted until 1918. After the October Revolution Russia adopted the Gregorian calendar. According to the Gregorian calendar the actual date is 15 October. The dates in Meshcherskiy's travel diary were written according to the Julian calendar, however in order to prevent confusion in dates, henceforth I will use only Gregorian calendar within the text and include Julian calendar date in the footnote.

911 November in Julian calendar.

10 4-5 October in Julian calendar.

11 6-9 October in Julian calendar.

1210 October in Julian calendar.

13 11-24 October in Julian calendar.

1426 October in Julian calendar.

1527 October-5 November in Julian calendar.

16 5-6 November in Julian calendar.

17 6-7 November in Julian calendar.

18 8-9 November in Julian calendar.

19 10-11 November in Julian calendar. 
Meshcherskiy's diary begins with the description of the first day of the journey. ${ }^{20}$ There is no prologue or introduction in the beginning of the diary. This travel diary was published in 1878. It was not republished during and after the Soviet Era.

The content of the diary can be divided into three parts. The first part contains his observations from the train, where he had little interaction with the military and administrative staff. It includes his analysis of Russian intellectual and social life, as well as a critique of international politics. ${ }^{21} \mathrm{He}$ writes about his conversations with officials and ordinary people throughout the journey, and focuses mostly on Russian society's position towards the ongoing war. But the people, whom Meshcherskiy talks to, do not seem to be too much interested in talking about the war. ${ }^{22}$ The first part also includes themes around the war and the Caucasus front. Meshcherskiy mentions the news about the ongoing war he receives via telegraph bulletins. In Vladikavkaz, he goes out to see the city and visits the hospital to talk to the wounded Russian soldiers and commanders. Wherever he stops over during the journey, he tries to describe the surrounding and the sociological and psychological situation of its local people. ${ }^{23} \mathrm{He}$ also describes buildings, the weather and the landscape of the cities.

The second part, the Russian attack on Kars, starts with the section 'Vizinkev, pod Karsom, noch s 5 na 6 noiabria, 11 chasov vechera. ${ }^{24}$ This section mostly includes Meshcherskiy's dialogues with the soldiers and generals. Most of these dialogues are about who was about to win the war, how many soldiers were injured and lost on the Russian side. He tries to understand and clarify the current course of the war; therefore he includes his dialogues with eyewitness soldiers and general from the battlefield, and especially the wounded ones in hospitals. ${ }^{25}$ Moreover, he includes dialogues with doctors, medical personnel, Turks, local administrative and military personnel. ${ }^{26}$ The siege of Kars took place on the night of 17-18 November 1877, ${ }^{27}$ when Meshcherskiy was at the village of Ardost near Kars. In the subsequent parts of this section, he describes the battlefields which he visited after the takeover of Kars. He also provides remarkable details about the city center of Kars, its people and the atmosphere among the inhabitants after the attack.

20 The first part starts with "Monday, 3 October, Ryzanskaia Zheleznaia doroga," Meshcherskiy, Kavkazkiy Putevoy Dnevnik, p. 1.

21 Meshcherskiy, Kavkazkiy Putevoy Dnevnik, pp. 2-5.

22 Meshcherskiy, Kavkazkiy Putevoy Dnevnik, pp. 5-6, 9-13, 20-23.

23 Meshcherskiy describes the Armenians as being the richest people in Tiflis, Kavkazkiy Putevoy Dnevnik, pp. 57, 122-124, 148.

24 Meshcherskiy, Kavkazkiy Putevoy Dnevnik, p. 219.

25 Meshcherskiy, Kavkazkiy Putevoy Dnevnik, pp. 70, 128-129, 171-172, 177-179, 194-200, 204-210, 220-255, 269, 272-273, 307-314.

26 Meshcherskiy, Kavkazkiy Putevoy Dnevnik, pp. 76-81, 336-339, 136, 159.

27 5-6 November according to Julian calendar. 
At the end of the text there is an epilogue (Prilozhenie) ${ }^{28}$ which can be considered as the third part. Throughout this final part he shares information about his travel from Kars to Moscow. These additional notes provide information on the interesting news he got on his way back to Moscow. In the final six pages ${ }^{29}$ of the epilogue, he writes his main impressions along his journey to the Caucasus. These impressions read like a summary to an official report. It is probable that when he wrote this diary he had in mind that it would be presented to the Tsar. In fact, this diary was published after his return to St. Petersburg, and Meshcherskiy sent a copy of the published work to the Tsar with a letter mentioning the campaign and his journey. ${ }^{30}$

This diary is a valuable source as much for economic history as well as military history, since it describes the prices of foods, drinks, travel costs, clothes, accommodation and even the prices of animals for sale. These prices are expressed in terms of rubles and kopeks. ${ }^{31}$ Furthermore, Meshcherskiy provides very detailed information about the Red Cross at the Caucasian Front. He describes the Red Cross hospitals, compares their function and adequacy to the Russian military hospitals at the front. ${ }^{32}$ There are few publications analyzing the structure and activities of the Red Cross at the Caucasian front during the 1877-78 war, yet none of them mentions Meshcherskiy's diary. ${ }^{33}$ Consequently, the diary would provide a valuable source in terms of future research on the Red Cross at Caucasian front.

Before going into the details of Meshcherskiy's travel diary, it would be useful to have a short biographical sketch of him. Prince Vladimir Petrovich Meshcherskiy (1839-1914) was a publisher and novelist who also served as adviser to Tsar Alexander III. Meshcherskiy was the grandson of the Russian historian Nikolay Karamzin. He enjoyed a large network of government circles and wrote many articles on the high life of St. Petersburg. He founded the journal Grazhdanin in 1878, and served as editor. ${ }^{34}$ In its day, this journal was the most

28 Meshcherskiy, Kavkazkiy Putevoy Dnevnik, pp. 357-372.

29 Meshcherskiy, Kavkazkiy Putevoy Dnevnik, pp.368-372. (There are two separate pages with the page number 368)

30 This diary was published as supplement to the journal Moskovskie Vedomosti (October-November, 1877), V. M. Meshcherskiy, Pisma k Velikomu Kniaziu Aleksandru Aleksandrovichu, 1869-1878, Novoe Literaturnoe Obozrenie 2014, p. 531.

31 Meshcherskiy, Kavkazkiy Putevoy Dnevnik, pp.16, 27-28, 30-31, 44-45, 48, 100, 110-111, 113, 117, 122, 132134, 194, 221, 340, 346, 352, 369.

32 In his diary Kavkazkiy Putevoy Dnevnik the pages where Meshcherskiy mentions Red Cross are as follows, pp. 46-47, 74-79, 80-84, 89, 109-118, 141-143, 157-158, 161, 182, 217-218, 361-368.

33 See Olga O. Chernyshova, 'The Female Face of War. The Sisters of mercy during the Russo-Ottoman War of 1877 - 1878,' Balkanistic Forum, No.3, 2016, pp. 42-51. Dağlar Oya Macar, 'Transportation of the Wounded during the Russo-Turkish War of 1877 - 1878,' Osmanlı Bilimi Araştırmaları XIX, 'Savaş ve Bilim 'Özel Saylsı (2018), 60-86. For the Red Cross activities at the Balkan front see Sena Hatip Dinçyürek, British Relief to the 93'Refugees (1877-78), Libra, Istanbul 2013.

34 Meshcherskiy was also the employer of Russian novelist Michael Fyodorovich Dostoyevsky. V. P. Meshcherskiy, Moi Vospominaniia, Zakharov, Moscow 2003, p. 3. 
reactionary paper in Russia. ${ }^{35}$ He opposed firmly all the liberal reforms and any revolutionary attempts and favoured the autocratic conditions that Russia had before the Russo-Japanese War. ${ }^{36}$ He died on 23 July 1914 at St. Petersburg. ${ }^{37}$

\section{Background to the Caucasian Theatre of War and the Battle of Kars}

On 24 April 1877, the Russian Empire declared war on the Ottoman Empire initiating a conflict later called the Russo-Turkish War of 1877-78. This was the fifth war between the two empires in the nineteenth century. Unlike previous wars, the 1877-1878 War received popular support from the Russian public, especially the inhabitants of Moscow and St. Petersburg where there was an organized Pan-Slavic community, including political elites and intellectuals. ${ }^{38}$ When the Russo-Turkish War started, the Russian army moved in two directions: the Balkans and the Caucasus. The main aim of the Russian army was to gain ground in the Balkans. However, in the course of the war Russians considered that their success depended also on their strength along the Caucasus line. On the other hand, the Turkish forces lacked an operational war plan. The Ottoman army was weak compared to Russians on the Eastern front; ${ }^{39}$ the Turkish Pashas' plans were based mostly on a defensive strategy. The Turkish army neither strengthened its forts nor prepared a useful defense plan, as they were relying on the tough geographical conditions of Kars, Ardahan and Erzurum. ${ }^{40}$

On 17 May 1877, Ardahan was the first region to fall to the Russians. ${ }^{41}$ Within a month the Russians took eastern Beyazit and started marching further east. By June, the Russians headed for Kars and started to threaten Erzurum. ${ }^{42}$ Early studies evaluate the assault on Kars as one of the most successful battles that showed Russia adopting high-level tactics against its enemy. ${ }^{43}$ Russian strategy was based on taking Kars before attacking Erzurum. ${ }^{44}$ Being aware of Russians' plan, Turkish field marshal Ahmed Muhtar Paşa took all the precautions to

35 For a period of time in 1903-1904 he was disfavored. But later on he gained the confidence of the Tsar Nicholas II. Meshcherskiy, Moi Vospominaniia, p. 3.

36 During the Russo-Japanese War he supported to compromise with Japan, in order to prevent revolution and to preserve autocracy. Meshcherskiy, Moi Vospominaniia, p. 3.

37 'Czar's Adviser, Mestchersky Dies,' The New York Times (24 July, 1914).

38 Drury, ibid, p. 3; There was an increase of Slavic nationalism in the second half of the nineteenth century, see Aslı Yiğit Gülseven, 'Rethinking Russian pan-Slavism in the Ottoman Balkans: N.P. Ignatiev and the Slavic Benevolent Committee (1856-77), Middle Eastern Studies, 53 (2017/3), pp. 332-348.

39 Greene, ibid, pp. 380-381.

40 Meriç Aybar, '1877-1878 Osmanlı Rus Harbinde Erzincan, in Hüsrev Akın, ed., International Erzincan Symposium, Proceedings, 28 September-1 October 2016, 1, Erzincan University Faculty of Law, Erzincan 2016, pp. 93-101; Greene, ibid, pp. 377-379.

41 Greene, ibid, pp. 382-383.

42 Aybar, ibid, p. 96; Drury, ibid, pp. 14-15.

43 Allen, ibid, p. 201. Details of the fall of Kars can be followed in Allen and Muratoff, ibid, pp. 201-211.

44 Aybar, p. 96; Drury, pp. 14-15, However, the Ottoman army strengthened the defense of Kars, with the forts built at the Karadağ, Çakmak, Çorak heights, and also Veli Paşa Tabia. Allen, ibid, p. 201. 
defend the Kars fortifications. Turkish fortifications and precautions impressed the Russians. ${ }^{45}$ On 25 June, ${ }^{46}$ the Russians laid siege to the eastern Kars fortifications and attacked Turkish troops, but failed. Muhtar Paşa sent troops to pursue the Russian soldiers who subsequently withdrew. ${ }^{47}$ Although the Russian army was defeated in the summer of 1877 , there was no definite success of the Turkish army. ${ }^{48}$ On 9 November ${ }^{49}$ the Russians attacked Erzurum but they could not take it. ${ }^{50}$ For the next time, the high command of the Russian army decided to manage a night attack. ${ }^{51}$ This took place on the night of $17-18$ November, ${ }^{52}$ and resulted in a victory for the Russians. ${ }^{53}$

By 5 January $1878,{ }^{54}$ the Russians completed their blockade of Erzurum. ${ }^{55}$ An armistice was signed on 31 January $1878 .{ }^{56}$ In March 1878, after the signing of the San Stefano Treaty, Erzurum surrendered to Russians. ${ }^{57}$ Later, the Berlin Treaty of 13 July 1878, Kars, Ardahan, Batum and Artvin were ceded to Russia and would remain under Russian control until the Brest-Litovsk Peace Treaty of 3 March $1918 .{ }^{58}$

In what follows, this article focuses on the important descriptive and analytical details found in the travel diary of Meshcherskiy. These details make us understand the above theater of war more clearly. Moreover, they also provide us with some crucial background and information about how successful was the Russian army and why the Turkish army was defeated at the Caucasus front.

45 General de Courcy, who was a French military attaché stated that the fortress is impregnable and that in case of an attack Russian army would lose many soldiers. Allen, ibid, p. 201.

4613 June 1877 in Julian calendar.

47 Drury, ibid, pp. 14-15; Greene, ibid, pp. 384-389.

48 At the same time, while the number of Turkish troops was gradually decreasing, the Russians increased their strength by bringing in new troops and ammunition. Muhtar Pasha was aware of the situation and informed Bab-1 Ali that the troops outside Kars could not resist a possible attack from the Russians. He asked to retreat to Kars, but as the authorities were expecting an armistice they refused this request. Aybar, ibid, p. 96.

4928 October in Julian calendar.

50 Greene, ibid, pp. 398-399; Allen, ibid, p. 204.

51 Allen, ibid, pp. 204-205.

52 5-6 November in Julian calendar.

53 In order to keep short the night marches for troops, he planned to attack simultaneously the forts of Hafiz, Kanlı, Süvari and Çim Tabia. Capturing these four Tabias, eased the way towards the town. However, one of the forts was more challenging than others: Karadağ Tabia. Therefore, General Lazarev planned to divide the unit into several columns, to confuse the Turkish army. Greene, ibid, pp. 403-404; Allen, ibid, p. 206.

5424 December 1877 in Julian calendar.

55 Within weeks there occurred scarcity of foods, Russian soldiers suffered from hunger for more than 10 days; besides there was a perishing cold, and not only soldiers but also horses were in a desperate situation. The typhus, which had already pervaded all over the city of Erzurum, spread within the Russian troop. More than 3000 Russian soldiers lost their lives. Allen, ibid, p. 211.

56 Allen, ibid, p. 212. 19 January 1877/1878 in Julian calendar. Double dating: 'Under the Julian calendar, the year number did not necessarily change on January 1.' See Stephen P. Morse, Converting between Julian and Gregorian Calendar, https://stevemorse.org/jcal/julian.html)

57 Although that was a Russian success, because of cholera and typhoid both Russian and Ottoman Armies suffered very badly. Drury, ibid, pp. 14-15.

58 Allen, ibid, p. 215. 


\section{The Battle of Kars in Meshcherskiy's Travel Diary}

\subsection{Poor conditions of the Russian Soldiers}

In his diary Meshcherskiy describes and criticizes the poor and challenging conditions of the campaign of the Caucasian army. The cold winter, inadequacy of food and warm clothes, and the poor medical help discouraged the Russian soldiers. Under these circumstances, the question mark in his and the Russian soldiers' mind was whether their success, despite all of these tough conditions, would be understood and appreciated by the Russian elites as it deserved to be. Meshcherskiy writes that the conditions under which the Russian forces had to campaign were so challenging that the soldiers were hungry almost all the time. ${ }^{59}$ The weather conditions were very harsh in Kars and Erzurum, and Russian soldiers lacked warm clothes and boots throughout the whole campaign. ${ }^{60}$ The diary emphasizes how Russian soldiers suffered more from the cold than from the fighting. On the evening of 18 November, ${ }^{61}$ many injured Russian soldiers were brought to the village of Ardost where the army hospital was located. Here they were offered tea, vodka and wine as first aid. Meshcherskiy writes that he personally brought 50 bottle of cognac to that hospital, and all of them were offered to the injured soldiers. ${ }^{62}$

Meshcherskiy intended to interview the injured soldiers in order to learn all the details about the attack, and the post-attack casualties. He arrived at Ardost on the evening of 18 November in order to investigate the state of the injured Russian soldiers and found that their number was not so high. ${ }^{63}$ The next day, however, more injured soldiers were brought to Ardost where, though the total capacity of the hospital was 600 people, there were now more than 1200 injured men. There was not enough bed and warm clothes. ${ }^{64}$ Not only the physical conditions but also the medical competence of the Russian army was very weak on the front. Witnessing those tough conditions under which the Russian soldiers were fighting, Meshcherskiy wondered whether their endeavor would be understood by the political elite and intellectuals of Russia. In his diary he records being worried that this success and these Russian soldiers would not get the attention they deserved from the Russian public. He writes 'I wonder whether they [elites in Moscow and St. Petersburg] would understand or not what kind of place is Kars, that the Caucasian Army has taken, [and] how important it is. Only once in hundred years can such a military mastery be demonstrated. ${ }^{65}$ Not only Meshcherskiy but also the soldiers on the front were resentful towards the indifference of the elites of Russia.

59 Meshcherskiy, Kavkazkiy Putevoy Dnevnik, p. 221.

60 Meshcherskiy, Kavkazkiy Putevoy Dnevnik, p. 238.

616 November in Julian calendar

62 Meshcherskiy, Kavkazkiy Putevoy Dnevnik, pp. 268-269.

63 Meshcherskiy, Kavkazkiy Putevoy Dnevnik, pp. 268-269.

64 Meshcherskiy, Kavkazkiy Putevoy Dnevnik, p. 270.

65 Meshcherskiy, Kavkazkiy Putevoy Dnevnik, p. 272. 
Meshcherskiy writes that when he arrived at the battlefield near Kars, where he encountered for the first time the dead bodies of Russian soldiers, one of the survivors told him that 'News was flying all over the Russia, and joy and delight were everywhere. And how many [Russian] people will think about them [the dead soldiers]? Where are their wives, where are their mothers? When will they find out [that these soldiers are dead]?'66

According to Meshcherskiy, in addition to the winter conditions and equipment shortages, the suffering of the Caucasian army's during the Kars campaign was also to some extent a result of the failures at the administrative level. He notes that the Grand Duke Mikhail Nikolayevich, who was the field marshal and the Governor General of Caucasia, confessed to Meshcherskiy that Russian soldiers suffered because of failed decisions during the planning of the attack. During his conversation with Meshcherskiy in the morning of 19 November, ${ }^{67}$ Nikolayevich admitted feeling sorry when remembering the unfortunate events that the Russian troops had to go through back in the summer (June) of $1877 .{ }^{68}$ Meshcherskiy observes that the Grand Duke's eyes were filled with tears while talking about those days. ${ }^{6}$ He told Meshcherskiy: 'We made many mistakes and faults, because of our ignorance and inexperience. We made amends for our mistakes before the Tsar and Russia, but whatever our mistakes were, one thing I can say, is that my main consideration was always to protect and protect our soldiers. ${ }^{70}$ According to Meshcherskiy's diary, complaining about the inadequacy of the medical facilities, the Grand Duke also stated that the timing of the first attack to Kars of 31 October $1877,{ }^{71}$ which resulted in failure, was also part of the unsuccessful decision making at the administrative level. He told Meshcherskiy 'There are many mistakes there [31 October], the main mistake was that we had not taken into account the winter [conditions] on time; however, fortunately, the Red Cross ${ }^{72}$ helped us a lot...' ${ }^{73}$ What the Grand Duke meant by not considering the winter on time was the failure of 31 October.

Meshcherskiy also provides details about this initial attack on Kars. The plan of attack took its exact form and the campaign had started at that date, but it had to be stopped because of a snowstorm which delayed the assault. However, it proved impossible to camp in the tents at 12 degrees under the ice and snow. The diary indicates that Russian soldiers should have either been withdrawn to winter headquarters by cancelling the Kars blockade, or they should

66 Meshcherskiy, Kavkazkiy Putevoy Dnevnik, p. 270.

677 November in Julian calendar.

68 Meshcherskiy, Kavkazkiy Putevoy Dnevnik, p. 275-276.

69 Meshcherskiy, Kavkazkiy Putevoy Dnevnik, p. 274-277.

70 Meshcherskiy, Kavkazkiy Putevoy Dnevnik, p. 276.

71 On 16 June 1855, Russia first attacked Kars fortifications, which resulted in a Russian failure. Reid, ibid, p. 291.

72 In many parts of his travel diary Meshcherskiy gives details about the structure and the service of the Red Cross towards Russian soldiers during the Caucasus Theater of War.

73 Meshcherskiy, Kavkazkiy Putevoy Dnevnik, p.277. 
have attacked as soon as possible. When their commander asked soldiers what they would have done, they answered that they would have preferred to attack, 'at least to get warm.'74 From these detailed notes on the confessions of the Grand Duke, we can deduce that the attack on Kars back in June and October 1877 proved a lesson for the Russian commanders. They saw the vulnerable points of the Russian forces and had developed a high-level strategy for the next attack. It is probable that these failures contributed to the subsequent Russian success on 18 November. ${ }^{75}$

\section{2. 'Hopeless Russian Soldiers and Commanders'}

Scholarship on the Russo-Turkish War of 1877-1878 does not include insider information from the front, especially about the local atmosphere during the course of the war. Meshcherskiy's diary, which includes conversations and interviews with the Russian soldiers and commanders in the field, provides a valuable source which supplements official accounts. From this diary, we can deduce that Russian soldiers were unwilling to attack Kars, and the general motivation for an attack was very low since both the soldiers and majority of commanders held little hope that the assault would succeed.

Meshcherskiy got the first impression about that unwillingness when he reached Vizinkev, near Kars, and heard that there would soon be an attack to Kars. Having heard about that news, the soldiers who were accompanying him became frustrated, and the one who gave that news noticed that '[The Turks] would repel them ... there is no chance of conquering Kars. ${ }^{{ }^{7} 6}$ A famous French military attaché, General de Courcy, who was greatly respected by the Russian soldiers, had quit the place just before the attack. Meshcherskiy states that he found it very interesting that a general, who was always ready and willing to take part in the campaigns, did not want to stay to witness the Kars attack. When General de Courcy was asked why he was leaving the field he answered, 'I do not want to see the result of the attack... I love the Caucasian army so much that I cannot stand seeing its inevitable bad fortune. Kars can never be captured!' 77 Not only the Russian soldiers, but also a very experienced French general, saw no chance of capturing Kars. Meshcherskiy often observes how none of the soldiers were willing to attack Kars; and both psychologically and physically they were not ready. ${ }^{78}$ His accounts in the diary indicate how the Russian soldiers and commanders were hopeless, even during the night of attack of 18 November when the soldiers felt they were viewed as worthless by the authorities, claiming that 'Russian soldiers were being thrown into the fire in vain. ${ }^{79}$

74 Meshcherskiy, Kavkazkiy Putevoy Dnevnik, pp. 255-256.

756 November in Julian calendar

76 Meshcherskiy, Kavkazkiy Putevoy Dnevnik, pp. 227-228

77 Meshcherskiy, Kavkazkiy Putevoy Dnevnik, p. 273

78 Meshcherskiy, Kavkazkiy Putevoy Dnevnik, p. 234

79 Meshcherskiy, Kavkazkiy Putevoy Dnevnik, p. 234. 
At this point Meshcherskiy mentions an interesting moment. Before the Deveboynu battle, the Russian General Vasiliy Geyman gathered all the generals and consulted whether to attack or not. All of them answered that Kars was an 'unconquerable' place. However, General Geyman told them that that was an order, and that Kars should be taken at all costs. ${ }^{80}$ On the other hand, in addition to General Geyman, the Grand Duke also confessed that he was pessimistic about the conquest of Kars. Meshcherskiy writes that after the fall of Kars, when the Grand Duke was at the top of Kars castle, he looked at the Karadağ and Arab Tabya (reinforcements) and told him: 'If I had seen Karadağ and Arab from this angle before, I would not have ordered to attack Kars. Anyone who would see these giant forts up close would be convinced that they were impossible to reach. ${ }^{81}$

\subsection{The Success of the attack}

Although the Caucasian Army was neither willing nor ready for the attack on Kars, it ended with the triumph of the Russian army. Meshcherskiy argues that the success was mainly based on three factors. For him the main reason for that success was primarily the deficiencies of the Turkish army, and secondly - and most importantly - the timing of the attack, and finally the planning of the attack.

\subsubsection{The Failure of Turkish army}

Meshcherskiy provides interesting details about the military tactics and equipment of the Turkish artillery. He writes that on the night of the attack a continuous noise passed over his head, and a soldier explained him that it was a burst of fire from rifles belonged to the Turks, indicating that 'Turks were using lousy rifles, which can shoot up to 16 times.' The soldier maintained that in return Russians were only shooting once with longer intervals. Here, Meshcherskiy records a tactical nuance distinguishing the two armies and how the Caucasian Army succeeded in turning the tactical failure of the Turks to their own advantage. ${ }^{82}$ When Meshcherskiy visited the upper forts of Süvari and Kanlı Tabya at the end of the attack, he also noticed the sacrifice and endeavor of the Turkish soldiers, and he states in his diary that they defended their positions very bravely. ${ }^{83}$ It seems that Meshcherskiy wondered why the Kars forts could not be defended by the Turkish army despite the effort and sacrifice of its soldiers.$^{84}$ One of the engineers who was visiting the military field with him after the assault noticed that there was a big deficiency of the Turkish fortifications: notably the absence of escarpments. Meshcherskiy indicates that 'if they [escarpments] had been also inadequate at Kars fortress then the attack would have been easier.' 85

80 Meshcherskiy, Kavkazkiy Putevoy Dnevnik, p. 237.

81 Meshcherskiy, Kavkazkiy Putevoy Dnevnik, p. 344.

82 Meshcherskiy, Kavkazkiy Putevoy Dnevnik, p. 229.

83 Meshcherskiy, Kavkazkiy Putevoy Dnevnik, pp. 290-291.

84 Meshcherskiy, Kavkazkiy Putevoy Dnevnik, p. 291-293.

85 Meshcherskiy, Kavkazkiy Putevoy Dnevnik, p. 293. 
Meshcherskiy records that when he got to the top of the mountain the day after the attack, he realized that each fort was terribly inaccessible. In addition, he noted that without taking all the forts, the Russians could not hold on to any of them since Russian soldiers would be caught in the crossfire between the forts. ${ }^{86} \mathrm{He}$ draws attention to the tactical fault of the Turkish army, ${ }^{87}$ stating that if Turks had cleared several forts and concentrated all their forces in two or three of them, Kars would not have been taken, and Russians would have had to abandon the fortifications they had already taken. ${ }^{88}$

Meshcherskiy also remarks that another deficiency of the Turkish army was the inadequacy of the required medical facilities and the corruption among the military and medical personnel. He mentions that, while visiting the Turkish hospitals at the front following the seige, he asked about the Turkish doctors and sanitary men. The answers lead him to conclude that 'there was not any Turkish doctor. There were only some paramedics who with the title of doctor performed only one thing: robbing the patients at every opportunity, even taking their food. ${ }^{89}$ He met some Turkish sanitation engineers wearing armbands with the Red Crescent. Some of them were speaking in English and others in French. One told that the Turkish commander of Kars went so far as to order everyone to hand out guns and shoot the enemy. The sanitation officer, 'under the threat of being hanged,' remarked to the commander that, 'on the basis of the Geneva Convention, the hospitals were protected from the enemy's attack, and that they themselves could not in any case use their weapons, and that it is banned equally for patients and sanitary officers. ${ }^{\prime 90}$ Meshcherskiy writes that the commander did not care about the Geneva Convention and repeated his order. But the sanitation officer did not follow that order. ${ }^{91}$

\subsubsection{The Sudden Attack}

According to Meshcherskiy, the second and most crucial factor leading to the success of the Kars assault was its suddenness. ${ }^{92}$ His diary reveals that though the Russian commanders

86 Meshcherskiy, Kavkazkiy Putevoy Dnevnik, p. 346.

87 In his travel diary Meshcherskiy provides a vivid picture of Turkish lack of strategy with a specific incident. He writes that at Karadağ, Turks from the trench started to shoot Russians with very weak rifles. This encouraged the Russian soldiers and they climbed to the highest point and were divided in 2 units. One unit went to Ziyaret Tabya, the other to Karadağ Tabya. However, Turks were not expecting that move and as a result some of them ran to Arab Tabya. According to Meshcherskiy, the Turkish army was so unprepared that it took only one hour, from 9 to 10 o'clock in the evening, to take Karadağ, which was the most critical place for capturing Kars. Meshcherskiy, Kavkazkiy Putevoy Dnevnik, p. 296

88 Meshcherskiy, Kavkazkiy Putevoy Dnevnik, p., 345.

89 Meshcherskiy, Kavkazkiy Putevoy Dnevnik, p., 347-348.

90 The Geneva Convention of 1864 stipulates 'the protection of the wounded and sick on land and at sea' must be observed during conflicts. For more details see, Substantive and Procedural Aspects of International Criminal Law, eds. Gabrielle Kirk McDonald and Olivia Swaak-Goldman, vol.1, Kluwer Law International, The Hague 2000.

91 Meshcherskiy, Kavkazkiy Putevoy Dnevnik, p. 347.

92 Meshcherskiy, Kavkazkiy Putevoy Dnevnik, p. 293. 
did their best to keep the plan of the sudden attack a secret, the Turks expected an attack in the morning of 19 November. ${ }^{93}$ Moreover, he records that a Turkish commander confessed to the Russian generals that the Turkish high command had been expecting an attack on the Çorak heights, ${ }^{94}$ which would have meant repeating the same mistake made by N. N. Muravyov during the siege of Kars in $1855,{ }^{95}$ which had cost the lives of 10,000 Russians. Furthermore, Meshcherskiy notes that a Russian general said 'Turks, very naively, had difficulty in somehow understanding that in those 22 years we could become wiser to such an extent that that we won't repeat on purpose the same mistake... Turks concentrated all their main power and best army at 19 November at Çorak heights, waiting for an attack... [Therefore, while being focused there] they left the fortresses like Karadag ${ }^{96}$ and Arab Tabya with small garrisons and with totally incapable army units. ${ }^{97}$ According to Meshchersky, all in all, the Russian success lay in its on-point strategy, in 'the attack plan of Loris-Melikov, who was well aware of the weakness and vulnerabilities of Turks and that how much they could be panic-stricken after a sudden attack.' ${ }^{98}$

\subsubsection{The Plan of the attack}

Meshcherskiy gives credit to the well-prepared attack plan in his diary. According to the travel diary, after deciding to attack Kars on 17 November, ${ }^{99}$ what the Russian military authorities meant was to take the lower fortifications rather than to take Kars. That was understandable as the generals were hopeless about the success and the soldiers were tired and not prepared. He introduces the plan after an interview with a high Russian commander: 'if we can take the lower fortifications, we will take all the guns, take prisoners, and depart to winter quarters, destroying the fortifications.' But according to Meshcherskiy there were some problems at the practical level: The plan was designed by Loris-Melikov, and accordingly there were two tasks; to attack the lower forts and to make demonstrations at the upper forts in order to distract Turks' attention. At that point Meshcherskiy compares the plan of Melikov to the 1855 Kars attack plan of the Russian General Muravyov, who was in favor of attacking the upper forts. ${ }^{100}$ Moreover another difference between Loris-Melikov

938 November in Julian calendar.

94 In the diary many Russian sources pronounce 'Çorak heights' as Shorah hills (Shorahskie Visotı)

95 Nikolai Nikolaevich Muravyov-Karskiy (1794-1866).

96 As noted above, according to Meshcherskiy's diary Karadağ tabya was the key fort, the fall of which would easily open way to the fall of Kars. Meshcherskiy, Kavkazkiy Putevoy Dnevnik, p. 296.

97 Meshcherskiy, Kavkazkiy Putevoy Dnevnik, p. 294.

98 An interesting detail in Mescherskiy's diary is that Turks were not at all expecting that Kars to fall. Meshcherskiy interviewed a commander and he noticed that when General Geyman, after the successful Deveboynu battle, sat at the Muhtar Pasha's tent, a Turkish colonel came in to ask Muhtar Pasha about his instructions. When he saw Geyman, in place of Muhtar Paşa, he was in amazement. He was immediately taken prisoner. Meshcherskiy, Kavkazkiy Putevoy Dnevnik, p. 238.

996 November in Julian calendar.

100 In several secondary resources it was indicated as 'Shorahskie visotı' or 'Shorah heights.' Meshcherskiy called it 'Shorahskie visoti;' see note 100 above. 
and Muravyov's plans was that while Muravyov was for attacking in the morning, Melikov was planning to attack in the evening using the full moon. As Meshcherskiy notes, before the attack of 1877, the supreme military council under the leadership of the Grand Duke had discussed the timing of the attack for a long time, especially about whether it should have been on day or night. The majority of the commanders in the council voted for the day attack, just a few of them were for a night attack. The Grand Duke, having had learned some lessons from the failures in the past, decided to approve the decision of the minority. It is important to note that Meshcherskiy puts emphasis on the fact that more important than the timing was the suddenness of the attack. ${ }^{101}$

\section{People of Kars in Meshcherskiy's Travel Diary}

\subsection{The Russians and the Armenians at the Battle of Kars}

In addition to the plan and timing of the attack and the details of the campaign, Meshcherskiy offers interesting insights about the people of Kars and their relations to the Russian Caucasian army. One interesting detail is about Armenians' relations to the Russian army and general impression of the Russians about Armenians. Meshcherskiy notes that the Russians were biased against Armenians for being a separatist group. He writes: 'In fact, the Armenians perform their duty with seriousness. They serve Russia more than they serve a separatist organization.' ${ }^{102}$ During his travels, Meshcherskiy developed a very deep admiration and respect for general Loris-Melikov, who was of Armenian origin. That's why Meshcherskiy seems to be disturbed by the rumors about Melikov's identity. He writes in his diary: 'They mention that Loris-Melikov was the representative of Armenian influence [in the Russian army]. Loris-Melikov is Armenian, yes but associating him with Armenian influence, and ... with the Armenian separatism ... is ridiculous. ${ }^{103}$ Meshcherskiy also praises Armenians in his diary mentioning their remarkable bravery and fearlessness. He writes: 'We Russians need to blame ourselves for this sin [of being prejudiced against Armenians] we are very greedy to see everywhere, especially where we are sloppy ... the separator element in everything and in everything, without delving into the essence of the question ... isn't there more evidence that the people whom we consider to be separatists fulfill their duty of serving Russia perfectly rather than serving as representatives and leaders of some kind of separatist party.' 104 According to Meshcherskiy there was an 'Armenian question' within the military affairs in the Caucasus, and he underlines that Russians were ignoring this question. This question was about the existence of Armenians within the Caucasus army. Meshcherskiy emphasizes how Russians did not trust Armenians and did not want to see them in command

101 Meshcherskiy, Kavkazkiy Putevoy Dnevnik, pp. 256-257.

102 Meshcherskiy, Kavkazkiy Putevoy Dnevnik, pp. 320-321.

103 Meshcherskiy, Kavkazkiy Putevoy Dnevnik, p. 320.

104 Meshcherskiy, Kavkazkiy Putevoy Dnevnik, p. 321. 
of Russian troops. Yet Meshcherskiy thinks that if it had not been for the Armenians within the Russian army, it would not have been as strong as it was. ${ }^{105}$

\subsection{About the city and Turks}

Meshcherskiy's diary also contains his impressions of Kars as a city and its inhabitants. He compares the physical appearance of the Turks, their style of clothes, as well as the physical structure of the city with those of Europe. ${ }^{106}$ His impression of the Turks is generally favourable, finding Turkish people friendly and decent. ${ }^{107} \mathrm{He}$ also notices how the attitude of Turkish civilians towards the Russian soldiers and high-commanders was very positive. After the fall of the city, while talking to the Turkish landlord of his apartment in the center of Kars, he learned how on the night of the attack, Turkish soldiers asked their commanders to surrender several times. 'The elder son of our landlord loved Russians and went to the commander leading the deputation and asked him to surrender. In return, the commander hanged the poor man. ${ }^{108}$ When Meshcherskiy asked the landlord why they asked to surrender, the landlord answered:

Because we knew that the Russians won't harm us ... Many of us remember the Russians, when Generals Muravyov and Loris-Melikov were here ... we liked them very much because they were fair [to us]... [However,] [our Pashas] they're destroying us ... We wished that [the Russians had taken Kars]... we knew that you [Russians] will not interfere with our religion and won't offend us. We also actually knew that your commander Loris Melikov ... is a kind and honest person. If at Erzurum they had known about that, Erzurum also would have surrendered to the Russians; we shouldn't be afraid of Russians, you will not hang us like our [Turkish] commander. ${ }^{109}$

The diary also indicates that the day after the Kars fell to the Russian army, both Turks and Armenians were ready to accept Loris-Melikov as their governor. ${ }^{110}$

On 18 November, the day after the attack, Meshcherskiy toured the city and provides a vivid picture of the city that day. He describes Kars as a city that climbed up to the castle by passing through narrow streets. It consisted of steep slopes that were very difficult to climb

105 While praising the Armenian generals, Meshcherskiy also criticizes the young generation of Armenians for having separatist dreams. He writes 'It is without any doubt that Armenian people of low and middle class dig into the bowels of Caucasus life and suck it out all the power. They live and earn at the expense of Georgians and Russians. They are reluctantly going to the military service. Also among young Armenians you won't find brave soldiers and commanders. But you can find among them many nihilists.' Meshcherskiy, Kavkazkiy Putevoy Dnevnik, pp. 321-322.

106 Meshcherskiy, Kavkazkiy Putevoy Dnevnik, p. 335.

107 Meshcherskiy, Kavkazkiy Putevoy Dnevnik, p. 336.

108 Meshcherskiy, Kavkazkiy Putevoy Dnevnik, p. 336.

109 Meshcherskiy, Kavkazkiy Putevoy Dnevnik, p. 337.

110 Meshcherskiy, Kavkazkiy Putevoy Dnevnik, p. 350. 
with equipment. Kars stream was a fast flowing and beautiful river, which ran through the middle of the city with a bridge, a solid structure made from stones. On the river bank was the large cupola of a Turkish bath, which Russian soldiers visited when they reached the city. Meshcherskiy writes that he was fascinated by the Turkish bath and its artistic structure. Moreover, he states that in the Turkish houses were numerous paintings of flowers of white, red, yellow, and green. Mosques were almost everywhere and, in the Armenian neighborhood, there were Armenian and Catholic Churches. ${ }^{11}$

The day after the assault, at the entrance of the city, Meshcherskiy first of all noticed the narrow streets, and houses with two stories. There were no women to be seen, but children and old people looked out of windows and from the roofs. All the shops were locked. Every house had two or three windows sealed with a massive gap in the form of an eye in the middle; he notes that these were windows of harems. ${ }^{12}$ On the other hand he notices that in the city center, markets and shops were open and the center had already returned to its usual peaceful life; no one had a fear of war. ${ }^{113}$

Meshcherskiy also found interesting the customs of the Turks when welcoming guests. The owner of the house where Meshcherskiy stayed received him and the Russian commander, but did so unaccompanied by his wife. Meshcherskiy registered discomfort about this, stating that in Russian tradition guests were received by the wife of the host. But the Turkish landowner laughed and said that it is not appropriate to show his wife to any men. His Turkish host told him: 'I would bring you my wife and my daughter ... but you wouldn't see them anyway, only they would see you [behind their veils]. ${ }^{114}$ Meshcherskiy was curious about how many wives Turkish men generally had, indicating that, when asked, the landowner answered: 'everyone who wants to have peace at home should only have one wife. If someone would have more than one, he won't have peace: wives cannot get along in peace.' 115

\section{Conclusion}

Meshcherskiy's travel diary provides insight into the situation of the Russian Caucasian army and the Russian soldiers during the Russian attack on Kars of November 1877. It presents us with a vivid picture of the relation between local Turks and the Russian army after the fall of Kars to the Russians. In doing so, it adds a new dimension to our understanding of Russian attitudes towards Armenians in that period.

111 Meshcherskiy, Kavkazkiy Putevoy Dnevnik, pp. 339-340.

112 Meshcherskiy, Kavkazkiy Putevoy Dnevnik, p. 282.

113 Meshcherskiy, Kavkazkiy Putevoy Dnevnik, p. 350.

114 Meshcherskiy, Kavkazkiy Putevoy Dnevnik, p. 339.

115 Meshcherskiy, Kavkazkiy Putevoy Dnevnik, p. 338. 
What we gain from Meshcherskiy's travel diary is a new dimension on the crucial moments of the conquest of Kars and its people. We learn that while the Russian army was in bad shape and most were pessimistic about the conquest of Kars, the city fell to the Russians because of specific factors. Firstly, the timing of the attack had utmost importance. In his observations, Meshcherskiy emphasizes the difficulties presented by the winter conditions and why it was vital to conduct a night attack. Secondly, he attributes the success of the Russian troops to the inadequacy and lack of strategy of the Turkish forces. According to Meshcherskiy, although the Russians overestimated the strength of the Turkish forts, their well-planned strategy combined with a sudden night attack provided them with success.

Although Armenian elements have generally been considered by historians to have acted cooperatively with the Imperial Russian army at the Caucasus border, Meshcherskiy notes that Armenians were generally approached with prejudice and suspicion by Russians, especially in the military field. Another important observation of Meshcherskiy was the reaction of Turkish community in Kars towards the Turkish officials. He writes that both the local people of Kars and the military-medical personnel were annoyed with the Turkish military officials, and that they warmly welcomed Russian officials after the fall of the city.

Being an aristocrat, a publisher and a figure that has very close relations with the Russian high authorities, Meshcherskiy published his diary upon returning to Russia in 1878., perhaps hoping to shape Russian public opinion. Thus, it could also be that this travel diary helped to forge public opinion about the Turkish administration in the Caucasus. It is highly possible that his comments and observations about the local people, the Russian army and their relations were selective, subjective and partial. He tries to describe the war scene, focusing on the Caucasus Front of 1877. However, it seems that there are some gaps in his writings, which disrupt the flow of the text. First of all, he does not make any references to the overall sociopolitical situation of the period. He focuses on the local conditions rather than evaluating the general context in which the war was taking place. He says nothing about the ongoing battles at the Balkan front. His central and exclusive focus is on the Caucasian Front and on the general conditions of the Russian army. His accounts of the local people's complaints about Turkish officials and his compliments about Russian officials must be approached with discretion. He frequently describes scenes glorifying Russian army traditions, salutes, heroic stories and narratives from the front. He also does not seem to have a detailed understanding of the socio-political structure of the Ottoman state or of Russo-Ottoman relations. However, it could also be the case that he applies self-censorship.

Secondly, he ignores discord within the Russian army. An army is generally expected to experience some problems concerning the chain of command and order during a war. However, in Meshcherskiy's diary such problems are totally left out of analysis. His depiction of the Russian army gives the impression that he prefers not to reveal any discord within the 
Russian army. His conversations with the soldiers and generals seem to have been partially omitted. The dialogues start not from the beginning but from the middle of conversations. These probable textual re-arrangements could arise from the concern that this diary would be published after his return to Russia. In addition, it could be the case that Meshcherskiy wanted to keep the details about the Russian army in secrecy, particularly the total number of soldiers, commanders, artillery and other vital information on the army structure. Most probably, he obscured this kind of information from concern for national security.

All in all, although Meshcherskiy's travel diary should be read with a critical eye, it nonetheless remains an invaluable and unique primary resource that sheds light on the battle of Kars and the conditions of Kars and its inhabitants during, and in the immediate aftermath of the Russo-Turkish War of 1877-1878.

Peer-review: Externally peer-reviewed.

Conflict of Interest: The author has no conflict of interest to declare.

Grant Support: The author declared that this study has received no financial support.

Hakem Değerlendirmesi: Dış bağımsız.

Çıkar Çatışması: Yazar çıkar çatışması bildirmemiştir.

Finansal Destek: Yazar bu çalışma için finansal destek almadığını beyan etmiştir.

\section{References/Kaynakça}

Allen, William Edward David, Paul Muratoff, Caucasian Battlefields, A History of Wars on the TurcoCaucasian Border, 1828-1921, Cambridge University Press, New York 1953.

Anderson, M. S., The Eastern Question, 1774-1923: A Study in International Relations, St Martin's, New York 1966.

Aybar, Meriç, '1877-1878 Osmanli Rus Harbinde Erzincan,' ed. Hüsrev Akın, International Erzincan Symposium, Proceedings, 28 September-1 October 2016, 1, Erzincan University Faculty of Law, Erzincan 2016, pp. 93-102.

Barry, Quintin, War in the East: A Military History of the Russo-Turkish War 1877-78, Helion, Solihull 2012. Bitva za Kavkaz v issledovaniiakh, dokumentakh i fotomaterialakh, ed. S. I Lintsa, PGLU, Pyatigorsk 2015.

Chernyshova, Olga O., 'The Female Face of War. The Sisters of mercy during the Russo-Ottoman War of 1877 - 1878,' Balkanistic Forum, No.3, 2016, pp. 42-51.

'Czar's Adviser, Mestchersky, Dies,' The New York Times (24 July 24 1914).

Dinçyürek, Sena Hatip, British Relief to the 93'Refugees (1877-78), Libra, İstanbul, 2013.

Drury, Ian and Raffaele Ruggeri, The Russo-Turkish War 1877, Osprey, London 1994.

Greene, F. V., Report on the Russian Army and its Campaigns in Turkey in 1877-1878, Appleton, New York 1879. 
Gorizontov, Leonid E. 'The Crimean War as a Test of Russia's Imperial Durability,' Russian Studies in History, 51, (2012/1), pp. 65-94.

Gülseven, Aslı Yiğit, 'Rethinking Russian pan-Slavism in the Ottoman Balkans: N.P. Ignatiev and the Slavic Benevolent Committee (1856-77),' Middle Eastern Studies, 53, (2017/3), pp. 332-348.

Kırımlı, Hakan, 'Emigrations from the Crimea to the Ottoman Empire during the Crimean War', Middle Eastern Studies, 44, (2008/5), pp.751-773.

Kolyubakin, B. M., Russko-Turetskaia Voyna, 1877-1878 gg. na Kavkaz i v Maloy Azii, Tipo-Tsintographiia A. G. Rozena, St. Petersburg 1906.

Lieven, Dominic, Empire: The Russian Empire and Its Rivals, Yale University Press, New Haven 2000.

Macar, Oya Dağlar, 'Transportation of the Wounded during the Russo-Turkish War of 1877 - 1878,' Osmanll Bilimi Araştırmaları XIX, 'Savaş ve Bilim’ Özel Sayısı (2018), pp. 60-86.

Meshcherskiy, V. P., Kavkazkiy Putevoy Dnevnik, 1878, Tipografiia G. E. Blagosvetlova, St. Petersburg 1878.

Meshcherskiy, V. P., Moi Vospominaniia, Zakharov, Moscow 2003.

Meshcherskiy, V. M. Pisma k Velikomu Kniaziu Aleksandru Aleksandrovichu, 1869-1878, Novoe Literaturnoe Obozrenie, 2014.

Morse, Stephen P., Converting between Julian and Gregorian Calendar, https://stevemorse.org/jcal/julian. html

Reid, James, Crisis of the Ottoman Empire, Prelude to Collapse 1839-1878, Steiner, Stuttgart 2000.

Rostunov, I. I., Russko-turetskaia voina 1877-1878, Voenizdat, Moscow 1977.

Substantive and Procedural Aspects of International Criminal Law, eds. Gabrielle Kirk McDonald and Olivia Swaak-Goldman, vol.1, Kluwer Law International, The Hague 2000.

Tanrıverdi, Mustafa, 'The Treaty of Berlin and the Tragedy of the Settlers from the Three Cities' in Hakan Yavuz and Peter Sluglett, eds., The Russo- Turkish War of 1877-78 and the Treaty of Berlin, Utah University Press, Salt Lake City 2011, pp. 449-478.

Yavuz, Hakan and Peter Sluglett, eds., War and Diplomacy. The Russo-Turkish War of 1877-78 and the Treaty of Berlin, Utah University Press, Salt Lake City 2011.

Zagiev, A. A., 'Osada Shturm Kreposti Kars Oseniu 1877 goda,'Vserossiyskie Millerovskie Chteniia, No.6, 2018, pp. 210-214.

Zolotarev, V. A., 'Rossiia i Turtsiia 1877-1878 gg.,' Nauka, St. Petersurg 1983. 
